\title{
Study on water saving strategy of students' dormitory in Chifeng University
}

\author{
Yuchen Yang ${ }^{1}$, Yaxin Zhang ${ }^{1 *}$, Qian Wang ${ }^{2}$, Xiaowei $\mathrm{Li}^{1}$, Ying Shuai ${ }^{1}$, Zixuan $\mathrm{Han}^{1}$, Qiang $\mathrm{Li}^{1}$, and Kunpeng Zhang ${ }^{1}$ \\ ${ }^{1}$ Departments of College of Physical and Intelligent Manufacturing Engineering, University of Chifeng, Chifeng, Inner Mongolia, China \\ ${ }^{2}$ Division of employment and Entrepreneurship, University of Chifeng, Chifeng, Inner Mongolia, China
}

\begin{abstract}
In order to solve the problem of waste of living water in Chifeng College Students' dormitory, the actual situation of water consumption in student dormitory was investigated. This paper analyzes the potential of water-saving and water-saving technology and strategy of Chifeng College, and finds out the water-saving mode suitable for the dormitory of Chifeng College. On this basis, the research on the application of reclaimed water treatment technology and the construction of reclaimed water treatment station in Chifeng university is carried out. This study provides theoretical and experimental support for solving the problem of water-saving in Chifeng College.
\end{abstract}

\section{Introduction}

Colleges and universities are the major water users in the city. Therefore, the research on water saving and energy saving in Colleges and universities can not only reduce the water consumption of colleges and universities and reduce the cost of running a school, but also cultivate students' awareness of water saving, advocate the civilized consumption mode of water saving, establish the social fashion of conscious water-saving, promote the improvement of water-saving awareness of the whole people, and improve the water-saving facilities of the whole country, so as to gradually expand the watersaving colleges and universities To the water-saving society, the realization of efficient utilization and rational allocation of water resources is of great significance to the construction of a conservation oriented society and adherence to the scientific outlook on development.

The main water consumption of Chifeng university is divided into teaching water, scientific research water, greening water, students' living water and commercial water. Among them, commercial water and greening water are generally calculated independently; teaching water mainly includes toilet water and flushing water in teaching building, and scientific research water is mainly laboratory water, which is necessary and accounts for a small proportion. This part is not discussed in this project. Students' living water is the toilet flushing water, washing water and drinking water in the student dormitory. This part of water accounts for a large proportion of the total water consumption, which is the top priority of water saving management in our university.

\section{Existing problems and solution}

\subsection{Existing problems}

At present, our school has not formed an effective watersaving strategy for students' dormitories, and the waste phenomenon is relatively serious

1.The students have poor water-saving consciousness.

There are many students with weak water-saving consciousness. For example, when washing face, some students who don't use washbasin turn on the faucet too much, while the students who use washbasin receive too much water: when washing, students who don't use washbasin usually can't tighten the faucet in time, no matter whether they need water flushing at that time or not. Therefore, it also increases the consumption of water, and the consumption is generally unused clean water. Water for brushing teeth, feet and hair is wasted due to excessive water.

2. Students' water consumption is not quantified, which results in water waste.

Our school did not install water meter and card water device in the dormitory, which caused many students to waste water when using water heater, even used hot water when mopping the floor and washing clothes, resulting in serious energy waste.

3 . The leakage rate of water supply network is high

The water supply pipe network of student dormitories has been built for a long time. Most of the water supply pipes are cast iron pipes, and some are cement pipes. So far, their service life has exceeded the service life. The aging of the pipe network is serious, and the leakage phenomenon is also serious, And the water supply network in the underground, often due to lack of funds,

* Corresponding author: zhangyaxin1981@126.com 
resulting in timely maintenance, will often run, run, drip, leakage phenomenon, resulting in a great waste of water resources.

\section{Unreasonable water supply design}

The double pipe water supply system of cold and hot water in students' bathrooms will cause a lot of hidden waste of energy and water resources when regulating the water temperature. Some high-rise student dormitories adopt the same water supply system. If the hydrostatic pressure in the bottom pipe is too high, a large amount of overpressure flow will be produced, which will cause invisible water waste.

5. Less use of water-saving appliances

The old style spiral lifting faucet, high-level automatic flushing water tank and hand-held flushing water tank are widely used in college students' dormitories. The cold and hot water double pipe water supply system is still used in the bathroom of the students' dormitory. The water-saving appliances are not installed in the dormitories and bathrooms in Colleges and universities, which will cause great waste of water resources. At present, China's water price is still on the low side. The economic loss caused by the waste of water in college students' dormitories is not big, so the university will not invest more funds to use water-saving equipment with higher price.

6. The management level of water resources is low

In order to carry out the water-saving work of College Students' dormitories in an all-round way, we must strengthen the management of water resources and improve the management mechanism of water resources in Colleges and universities. In many colleges and universities, the management system of valves in campus water supply network is not perfect, the original situation and statistical account are not fully recorded, and its management facilities are relatively backward; only a few colleges and universities implement water metering measures for students' dormitories, causing serious waste of water resources; and few colleges and universities adopt information, automation and other testing means for water supply network, The water resources management level of College Students' dormitories needs to be improved.

7. Less investment in water saving

It needs a lot of money to carry out the water-saving work of College Students' dormitory. Nowadays, the investment of water-saving work in Colleges and universities is less, which is one of the important factors hindering the water-saving work.

\subsection{Solutions}

According to the analysis of the survey results, the following four water-saving strategies are put forward.

1. From the relevant departments and colleges, we set up a research group to design a water use questionnaire. Through the investigation and analysis of the current water use level of Chifeng University, we use the quota comparison method to quantitatively estimate the watersaving potential of colleges and universities, and put forward corresponding water-saving measures to further tap the water-saving potential of colleges and universities.

2. Follow the example of central China Normal University, Yili Normal University, Fuzhou University, Beijing University of technology, China University of science and technology and other schools to carry out a lot of water-saving publicity, so that teachers and students can consciously save water.

Colleges and universities carry out water-saving construction, continuously carry out water-saving education for students, establish the habit of watersaving, and make it a living habit. It is not only a good attitude towards life, but also a responsible way of life for students to establish economy. Saving water not only saves water resources, but also creates value. Students will also influence this good habit to the people around them. With the water-saving consciousness affecting more people, saving water has gradually become the behavior of the whole society. To play this leading role, the influence is huge, and the achievement of water resources conservation is also huge.

3. Reform and improve the water management, strengthen the construction of water use system; replace the backward and aging water appliances with watersaving and energy-saving sanitary appliances; invest more funds to improve water supply equipment and infrastructure; carry out water balance test irregularly, reform and upgrade the measurement network system, and so on.

4. Introduce reclaimed water recovery technology into water saving in Colleges and universities. Reclaimed water reuse technology refers to the centralized treatment of domestic wastewater or sewage, which can be reused for greening irrigation, vehicle washing, road washing, toilet washing and so on, so as to achieve the purpose of saving water. Reclaimed water reuse can be used as the second source of water to improve the reuse rate of water.

\section{Reclaimed water recovery}

A variety of water-saving schemes have been put forward, but in terms of the actual situation of Chifeng University, the reclaimed water recovery technology is an effective means to solve these problems.

\subsection{Application of reclaimed water technology}

Reclaimed water reuse technology has been applied to practice in foreign countries. The United States, Japan and Israel are in the forefront of the world. These countries use reclaimed water as water for flushing toilets, farmland and landscaping irrigation, road cleaning, car washing, urban fountain, etc. Since the 1980s, Japan has vigorously advocated the use of reclaimed water, formulated various incentive measures, and actively promoted the reuse of reclaimed water. It also requires new government agencies, schools, enterprise office buildings, parks, stadiums and other public buildings to set up a reclaimed water system to use reclaimed water. At least seven areas in the United 
States have or are building reclaimed water reuse plants. In 2008, the number of reuse times of reclaimed water in the United States has been reduced by $45 \%$. Israel is the country with the most characteristics in reclaimed water reuse. Israel is short of water resources, and its per capita water resources are only 476 cubic meters. Therefore, the Countermeasures of agricultural water saving and urban reclaimed water reuse are adopted. $46 \%$ of the total amount of sewage treatment in China is directly reused for irrigation, and the remaining $33.3 \%$ and about $20 \%$ are respectively recharged underground or discharged into rivers. The speed of reclaimed water reuse ranks first in the world.

At present, $100 \%$ of the domestic sewage and $72 \%$ of the urban sewage in Israel are recycled. It can be seen that many foreign countries have made great progress in reclaimed water reuse. Especially in Colleges and universities, in the 1980s, Japan required colleges and universities to set up reclaimed water system and use reclaimed water. China began to use reclaimed water since the end of 1990s. At present, it has a certain scale, but there is a big gap between China and developed countries. By 2009, China's sewage recycling rate (sewage recycling capacity / sewage treatment rate) will be about $15 \%$, while the ratio of sewage recycling to sewage discharge is only about $5 \%$. Beijing, Tianjin, Qingdao and other areas with serious water shortage are at the forefront of reclaimed water reuse, which are included in the overall urban planning. According to the overall planning of Beijing, nine medium-sized water plants will be built in the urban area in 2008, so that the reuse rate of reclaimed water can reach $50 \%$. Tianjin has also issued special regulations on the use of reclaimed water in residential buildings. New residential areas with an urban planning area of more than 50000 square meters and residential areas with a planned population of more than 10000 people must use reclaimed water and must be equipped with reclaimed water pipes. At present, some communities in Tianjin use reclaimed water to replace tap water for landscape water and green space irrigation. Qingdao is also a typical water shortage city. Facing the increasingly serious water shortage situation, Qingdao vigorously promotes the reuse of reclaimed water.

At present, in China's universities, reclaimed water reuse has not been well popularized, but also has made certain achievements. For example, the reclaimed water treatment station of Beijing University of technology was built in 2003 with a design daily treatment capacity of $200 \mathrm{~m} 3$. The reclaimed water after biochemical treatment is mainly used for flushing toilets in student apartments, lawn greening on the north side of swimming pool, car washing and tree watering in gas stations. Yancheng Institute of technology began to pilot the reclaimed water reuse technology in the spring semester of 2002. The initial investment was more than 30000 yuan. Eight sets of reclaimed water reuse devices were made of stainless steel corrosion-resistant materials. They were used in an old dormitory building in the west campus. After practice and calculation, the cost was recovered in 10 months. Due to the remarkable effect of water-saving, it was fully promoted in the school in 2003.
Over 400000 yuan was invested once. 118 sets of stainless steel reclaimed water reuse devices were installed in all the remaining 12 non apartment dormitory buildings, saving more than 200000 cubic meters in that year. At present, Northern Jiaotong University, Central University for Nationalities and Beijing United University have established reclaimed water treatment stations to realize the reuse of reclaimed water. Reclaimed water is recognized as the second water source in cities all over the world. To create a watersaving society and water-saving campus, we must attach importance to and develop reclaimed water reuse technology, and effectively use our second water source.

\subsection{Site selection of reclaimed water station}

As the main supporting building of campus reclaimed water treatment system, the location of reclaimed water treatment station should consider the overall planning of campus, the overall environment, the drainage situation of each dormitory building, the layout of reclaimed water points in the campus and the operation and maintenance.

To set up a reclaimed water station in the dormitory area of the university is not only to remove all kinds of pollution in the drainage, but also to treat the sewage in the school to meet the discharge standard allowed by the city and supply the water to each water point in the school. According to this demand, the distance between reclaimed water station and dormitory buildings should be considered reasonably when setting up reclaimed water station. Try to be close to the main collection points and water consumption points of reclaimed water and raw water, and make the raw water flow into the treatment station by gravity flow as far as possible, so as to reduce the construction of drainage pump station.

In order to facilitate the transportation of sludge generated in the process of operation of the treatment station, there should be a separate transportation channel between the treatment station and the school. The noise and smell of equipment produced by reclaimed water treatment station in the process of sewage treatment will affect the daily living environment of the dormitory building in the dormitory area to a certain extent, which will cause harm to the campus environment. Therefore, in the construction site selection of reclaimed water station, all kinds of noise and odor pollution should be solved, and a reasonable distance from dormitory area should be kept. 


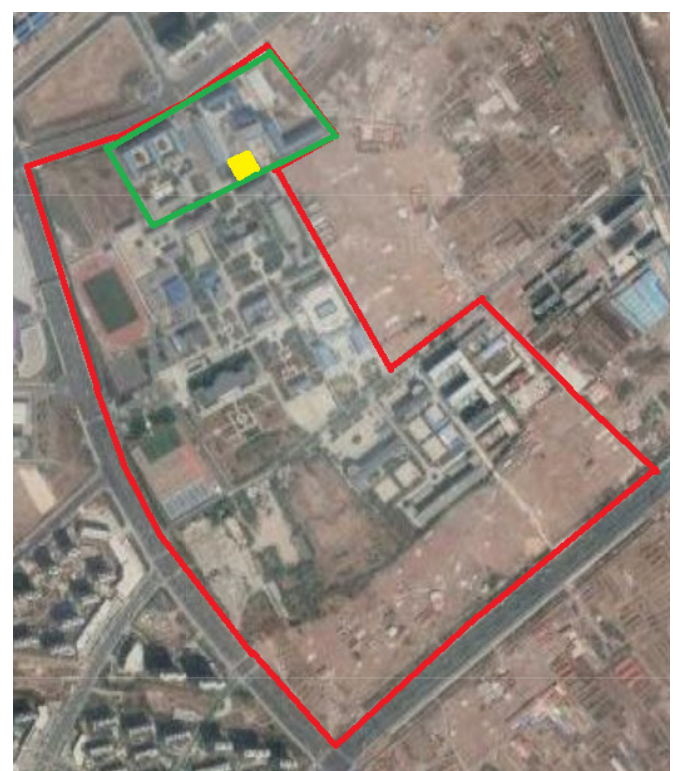

Figure 1 Satellite map of Chifeng University

The satellite map of Chifeng university is shown in Figure 1. The green area is the dormitory area, and the yellow area is the abandoned heating boiler room. Considering all aspects, the reclaimed water station of Chifeng university is located in the abandoned heating boiler room, as shown in Figure 2. Its advantages are as follows:

(1) The abandoned heating boiler room has enough space to install reclaimed water equipment.

(2) It is close to the access point of municipal pipelines, and the original pipelines of various systems can also be fully utilized.

(3) The location of each dormitory building away from the accommodation area is appropriate.

(4) The abandoned heating boiler room has an independent courtyard surrounded by trees, which is wind proof and sound insulation, and has little impact on the surrounding buildings;

(5) Equipment maintenance and waste removal can be carried out from the north gate of the campus, which has little impact on the campus.

\section{Conclusion}

In this paper, the water-saving strategy of Chifeng College Students' dormitories is studied. Based on the actual investigation of the water use situation of the students' dormitory, this paper analyzes the water-saving potential and water-saving technology and strategy of our university, and finds out the water-saving mode suitable for the actual situation of the dormitory in our university. On this basis, the research on the application of reclaimed water treatment technology and the construction of reclaimed water treatment station in Chifeng university is carried out.

\section{Acknowledgments}

This work was supported by Chifeng College Students' innovation and entrepreneurship training program in 2020 (DCXM2020014).

\section{References}

1. Wang Jianzhong. Research on reclaimed water treatment and reuse technology in green buildings [J]. Shanghai construction technology, 2013, (02): 27-30

2. Yang Maogang, Zhao Shuqi, Wang Qianxun, Chen Shuzhen. Review on the development of reclaimed water utilization abroad [J]. Haihe Water Conservancy, 2013, (8): 30-33

3. Zhu Li, sun Limi. Application of underground infiltration in sewage treatment of University Park [J]. Water supply and drainage, 2007, (6): 96-98

4. Liang Wei. Design of reclaimed water reuse system in Taiyuan University of technology [J]. Shanxi architecture, 2010, (29): 165-166

5. Su Yu, Dong Hongxiang, Zhang Zhenhua. Research on green campus construction in Higher Vocational Colleges [J]. Ningxia Agricultural and forestry science and technology, 2013, (08): 80-91

6. Zhou Jinshuo. Intelligent analysis of energy-saving construction of a university green campus -Discussion on the planning of green campus in Colleges and universities in China [J]. Resource conservation and environmental protection, 2013, (12): 15-16

7. $\mathrm{Xu}$ Jin. Green campus: the low carbon road of Tongji University [J]. Landscape, 2010, (10): 88-90

8. Lu Bin. International comparison of goals and measures of green campus construction [J]. Construction technology, 2013, (12): 30-36

9. $\mathrm{Xu}$ Xiaowei. Green building and green campus construction $[\mathrm{J}]$. China modern education equipment, 2014, (10): 34-37

10. Wu Zhiqiang, Wang zisong. Green Campus - for our common future - work of green campus group of China Green Building and energy conservation professional committee $[\mathrm{J}]$. Construction technology, 2013, (12): 16-19

11. Li Anfeng, pan Tao, Li Jian. Wastewater treatment and recycling project of a university [J]. China water supply and drainage, 2013, (8)

12. Huang Yechun. Discussion on the reconstruction of sewage treatment in University District [J]. Technology and market, 2014, (6): 52-53 